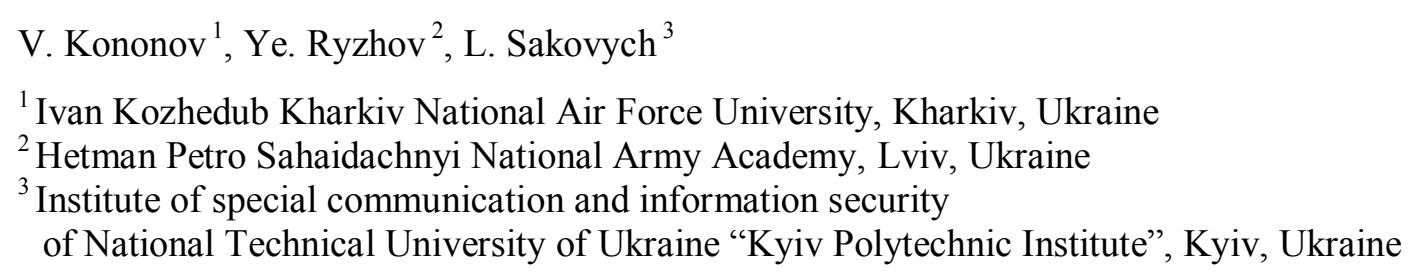

\title{
DEPENDENCE OF PARAMETERS OF REPAIR OF MILITARY COMMUNICATION MEANS ON THE QUALITY OF METROLOGICAL SUPPORT
}

\begin{abstract}
The article proposes an approach to the quantitative assessment of the effect of metrological reliability of measuring equipment on the time of the verification of the parameters of military communications means during its maintenance and current repairs. In known works, approximate values of the probability of failure-free operation of measuring instruments are used for this, which reduces the accuracy of the results obtained. In the field conditions, it is necessary to take into account the metrological reliability of measuring instrument, which depends on temperature, humidity, vibration loads and other factors. The time for determination of the technical state of military communications means is regulated by guidance documents, therefore it is necessary to take into account all factors influencing the values of maintainability indicators in order to plan efficient work of specialists during its technical maintenance and routine maintenance in the process of developing metrological and diagnostic support. It is suggested to use the functional dependencies of the average recovery time of military communications equipment on the quality indicators of metrological and diagnostic support. Examples are given of using the results of the study to quantify the maintainability of real samples of military communications means and show the gain in the accuracy of calculating the average recovery time. The received results allow to estimate more objectively time of performance of works and reasonably to choose measuring instruments more objectively.
\end{abstract}

Keywords : military communications means; measuring instruments; metrological support.

\section{Analysis of recent research and publications}

Military communication means (MCM) is continuously improving in the direction of raising the values of quality indicators, which leads to an increase in the number of elements, but the time required for maintenance and current repair (CR) remains unchanged.

Ref [1] discusses the relationship of metrology and technical diagnostics, but there are no recommendations on the justification of the choice of measuring instruments (MI). The solution of this problem is formulated in [2-5] without taking into account the influence of metrological reliability. The question of the metrological reliability of the MI is separately considered in [6-9], and recommendations for its inclusion during the maintenance and the CR of the MCM are given in $[10,11]$. In this case, the approximate values of the probability of non-failure operation of the MI are used, which significantly worsens the accuracy of the results of quantitative evaluation of the time of execution of works.

\section{Problem statement}

As a result of the combined consideration of the current achievements in the field of metrological and diagnostic support of maintenance and CR MCM, it is necessary to obtain the functional dependence of the indicators of maintenance on the metrological reliability of the MI.

Therefore, the purpose of the article is a quantitative assessment of the influence of the metrological reliability of the MI on the time of measuring the parameters of the MCM during its maintenance and $\mathrm{CR}$.

\section{Results}

During maintenance and $\mathrm{CR}$, the $\mathrm{MI}$ is used to determine the actual technical condition of the MCM.

In this case, the average recovery time $(T r)$ should not exceed the permissible value $(T p)$ given in the manual documents $[10,11]$

$$
\operatorname{Tr}=\left(t K+t_{t r s}\right) /\left(p^{K} \cdot \prod_{i=1}^{N} P_{i}(\tau)\right) \leq T p,
$$

where $t$ and $t_{\text {trs }}$ are the average time for checking and troubleshooting, respectively; $p$ is the probability of a correct assessment of the outcome of the verification depending on the type of MI; $N$ is the number of MIs used during maintenance and $\mathrm{CR} ; P_{i}(\tau)$ is the probability of failure-free operation of the MI in the form $i$ of inter-verification interval $\tau ; K$ is the average number of inspections to determine the technical condition of the MCM.

In this case, the values $0,85 \leq P_{i}(\tau) \leq 0,99$ are chosen roughly [8-11], which leads to significant errors in the determination of $\mathrm{Tr}$.

The peculiarity of the operation of the MI is due to ensurance of its reliability, mainly due to hidden metrological failures. Negative consequences of the use of MI with metrological failures can be extremely high and difficult to predict.

As indicators of the metrological reliability of the MI, the probability $P_{i}(\tau)$ of preserving the values of metrological characteristics in the set limits within the checking interval $\tau$ is used $[9,12]$.

The required level of metrological reliability significantly depends on the application of the MI and is 
selected from the condition of ensurance the required efficiency of serviced technical devices. As a rule, this level for the working MI is $0,85 \ldots 0,90$, but in the best cases can be $0,90 \ldots 0,99[9,12]$.

Quantitatively, the probability of preserving the values of the metrological characteristics of the MI in specific operating conditions can be estimated using the expression [9]

$$
P_{i}(\tau)=1-m \cdot K_{M} K_{S},
$$

where $m$ is the equivalent number of failures during operation

$$
m=\tau \cdot K_{U} / T,
$$

where $K_{M}$ is the proportion of metrological characteristics of the MI, which are not covered by built-in control; $K_{S}$ is the statistical estimation of the coefficient of latent failures, which characterizes the portion of metrological failures; $K_{U}$ isthe average rate of the use of the MI; $T$ - is the working time of the MI between failures.

Values $\tau$ are obtained from the manual documents for the metrological maintenance of the service objects or from the technical description of the MI.

It is known that the MCM repair operator directly deals with its restoration 900 hours during the year [13]. In this case, the rate of use of the MI at the point of maintenance and repair for the year of operation is equal to

$$
K_{U}=\frac{900}{8760}=0,103 .
$$

According to the results of the analysis of the technical description and manual of the MI one determines $K_{M}$.

Value of coefficient of hidden failures $K_{S}$ depending on the purpose of the MI in the absence of statistical data of the results of the operation of analogic devices are determined as an average of the values given in the table 1 [9] for different parameters.

Working time between failures of the MI is also taken from statistical data, and in the absence of technical descriptions of devices.

The mean square deviation of the estimation of the probability of preservation of the values of the metrological characteristics of the MI is calculated using the expression [9]:

$$
\sigma=m \cdot K_{M} \sqrt{K_{S}\left(0,15 \cdot K_{S}+1 / m\right)} .
$$

Table 1. Averaged values of the coefficient of hidden failures depending on the purpose of the MI

\begin{tabular}{|l|l|c|}
\hline № & \multicolumn{1}{|c|}{$\begin{array}{c}\text { Title of the parameter of the MCM } \\
\text { and appointment of the MI }\end{array}$} & $K_{S}$ \\
\hline 1. & Voltage & 0,1 \\
\hline 2. & $\begin{array}{l}\text { Parameters of components of electric circuits } \\
\text { with lumped constants }\end{array}$ & 0,21 \\
\hline 3. & Power & 0,23 \\
\hline 4. & $\begin{array}{l}\text { Parameters of elements and paths with } \\
\text { distributed constant }\end{array}$ & 0,22 \\
\hline 5. & Frequency and time & 0,16 \\
\hline 6. & Phase difference and group delay time & 0,2 \\
\hline 7. & Signal form and spectrum & 0,2 \\
\hline 8. & Features of radio devices & 0,16 \\
\hline 9. & Pulse signals & 0,16 \\
\hline 10. & Field voltage and radio interference & 0,18 \\
\hline 11. & Amplifiers measuring & 0,15 \\
\hline 12. & Measuring generators & 0,2 \\
\hline 13. & Attenuation & 0,21 \\
\hline 14. & Electrical and magnetic properties of materials & 0,16 \\
\hline 15. & Parameters of coaxial and waveguide paths & 0,21 \\
\hline 16. & $\begin{array}{l}\text { Parameters of radiolamps and semiconductor } \\
\text { devices }\end{array}$ & 0,24 \\
\hline
\end{tabular}

Let's consider an example of the application, which are used during maintenance and repair of the short-wave radio station R-1150 [14]. The results of calculations are given in table 2, for $\tau=8760 \mathrm{hr}$.

Table 3 gives the parameters calculated for different values of the time $\mathrm{T}$ for a short-wave radio station P-1150 operated by one master. The estimated time of execution of the maintenance increases by $5.5 \%$, when one accounts for the metrological reliability of the MI. During the CR of the short-wave radio station P1150 in case of a failure of the built-in control system, the search for a defective typical replacement element is performed using the conditional diagnostic algorithm shown in Fig. 1.

The object consists of $L=41$ elements, the time necessary to restore its working status is $T r=30 \mathrm{~min}$. The binary conditional diagnostic algorithm ensures the localization of the defect after performing $K=6$ checkings. For $t=3 \mathrm{~min}$ and $t_{y}=5 \mathrm{~min}$ for the analog voltmeters C-4353 or B3-56 $(p=0,845)$ as a MI without taking into account their metrological reliability, we obtain

$$
\operatorname{Tr}=\frac{6 \cdot 3+5}{0,845^{6}}=63 \mathrm{~min}>\operatorname{Tp},
$$

which reveals that, this option does not meet the requirements.

Table 2. Parameters calculated for short-wave radio station R-1150

\begin{tabular}{|c|c|c|c|c|c|c|}
\hline № & Measuring instruments & $T, \mathrm{hr}$ & $K_{M}$ & $K_{S}$ & $P_{i}(\tau)$ & $\sigma$ \\
\hline 1. & Electrometer-multifunctional device C-4353 & 1500 & 1,0 & 0,21 & 0,877 & 0,353 \\
\hline 2. & Power meter M3-45 & 2000 & 1,0 & 0,23 & 0,899 & 0,319 \\
\hline 3. & Frequency meter Ch3-63 & 3000 & 0,5 & 0,16 & 0,976 & 0,217 \\
\hline 4. & Non-linear distortion analyzer of C6-11 & 5000 & 0,1 & 0,16 & 0,997 & 0,054 \\
\hline 5. & Millivoltmeter B3-56 & 4000 & 1,0 & 0,10 & 0,978 & 0,148 \\
\hline 6. & High frequency signal generator G4-151 & 5000 & 0,3 & 0,20 & 0,989 & 0,187 \\
\hline
\end{tabular}


Table 3. List of parameters measured for the short-wave radio station P-1150

\begin{tabular}{|c|c|c|c|c|c|}
\hline \multirow[b]{2}{*}{ № } & \multirow[b]{2}{*}{ Parameter } & \multirow{2}{*}{$\begin{array}{l}\text { Measuring } \\
\text { instruments }\end{array}$} & \multirow[b]{2}{*}{$p_{i}$} & \multicolumn{2}{|c|}{ Time measurement, hours } \\
\hline & & & & $\begin{array}{l}\text { According to } \\
\text { instructions }\end{array}$ & $\begin{array}{l}\text { Taking into account the } \\
\text { metrological reliability }\end{array}$ \\
\hline \multirow{2}{*}{1} & \multirow{2}{*}{ Sensitivity } & C6-11 & 0,9993 & \multirow{2}{*}{2,33} & \multirow{2}{*}{2,36} \\
\hline & & G4-151 & 0,834 & & \\
\hline 2 & Power & M3-45 & 0,95 & 3,00 & 3,34 \\
\hline \multirow{2}{*}{3} & \multirow{2}{*}{ Range of manual gain control } & B3-56 & 0,85 & \multirow{2}{*}{0,25} & \multirow{2}{*}{0,26} \\
\hline & & G4-151 & 0,834 & & \\
\hline \multirow{2}{*}{4} & \multirow{2}{*}{ Automatic gain control range } & $\mathrm{B} 3-56$ & 0,85 & \multirow{2}{*}{0,16} & \multirow{2}{*}{0,16} \\
\hline & & G4-151 & 0,834 & & \\
\hline 5 & Frequency of reference generator & Ch3-63, clock & 0,9985 & 0,25 & 0,26 \\
\hline \multirow{2}{*}{6} & \multirow{2}{*}{$\begin{array}{l}\text { Non uniformity of the amplitude-frequency } \\
\text { characteristic of the receiving tract }\end{array}$} & G4-151 & 0,834 & \multirow{2}{*}{1,15} & \multirow{2}{*}{1,19} \\
\hline & & B3-56 & 0,85 & & \\
\hline \multirow{2}{*}{7} & \multirow{2}{*}{ Nonlinear distortion of the receiving tract } & G4-151 & 0,834 & 1,15 & \multirow{2}{*}{1,17} \\
\hline & & C6-11 & 0,9993 & & \\
\hline 8 & Power supply & C-4353 & 0,845 & 0,08 & 0,09 \\
\hline & Total execution tir & & & 8,37 & 8,83 \\
\hline
\end{tabular}

Using the digital voltmeter, by which the C6-11 is required $(p=0,9993)$ one obtains a positive answer, even taking into account the metrological reliability of the device

$$
\operatorname{Tr}=(6 \cdot 3+5) /\left(0,997 \cdot 0,9993^{6}\right)=23 \min <\operatorname{Tp} .
$$

Let's consider another example of the calculation with the conditional algorithm for diagnostics of the control subsystem of the operation of a high power radio transmitter, which is shown in Fig. 2 [11].

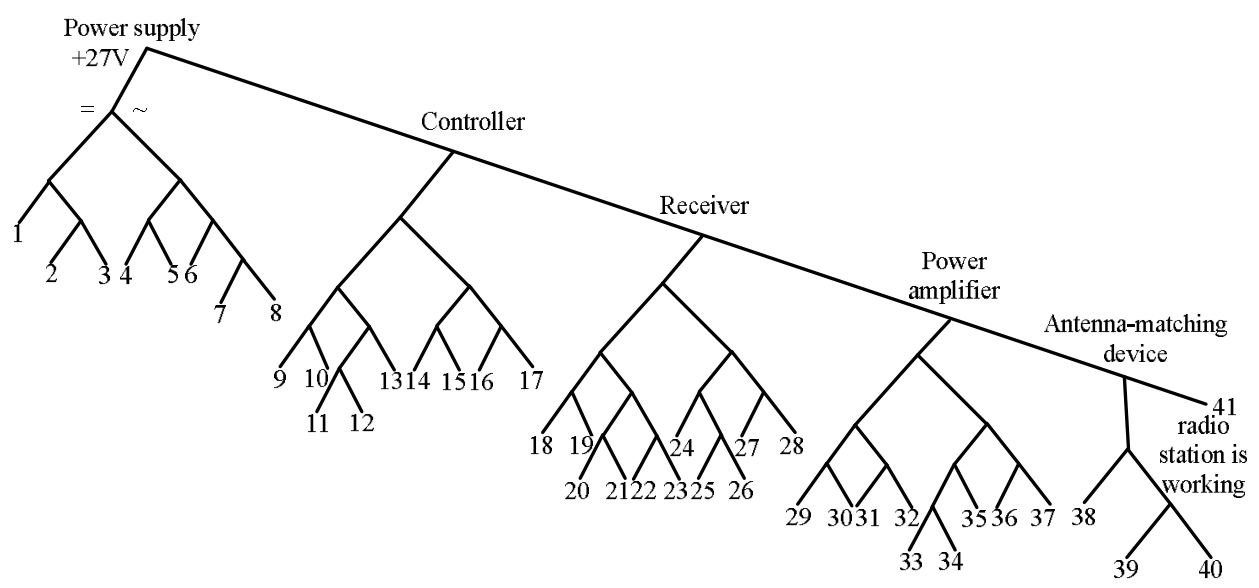

Fig. 1. Conditional algorithm for determination of the technical state of the short-wave radio station P-1150 with the failure of the built-in control system
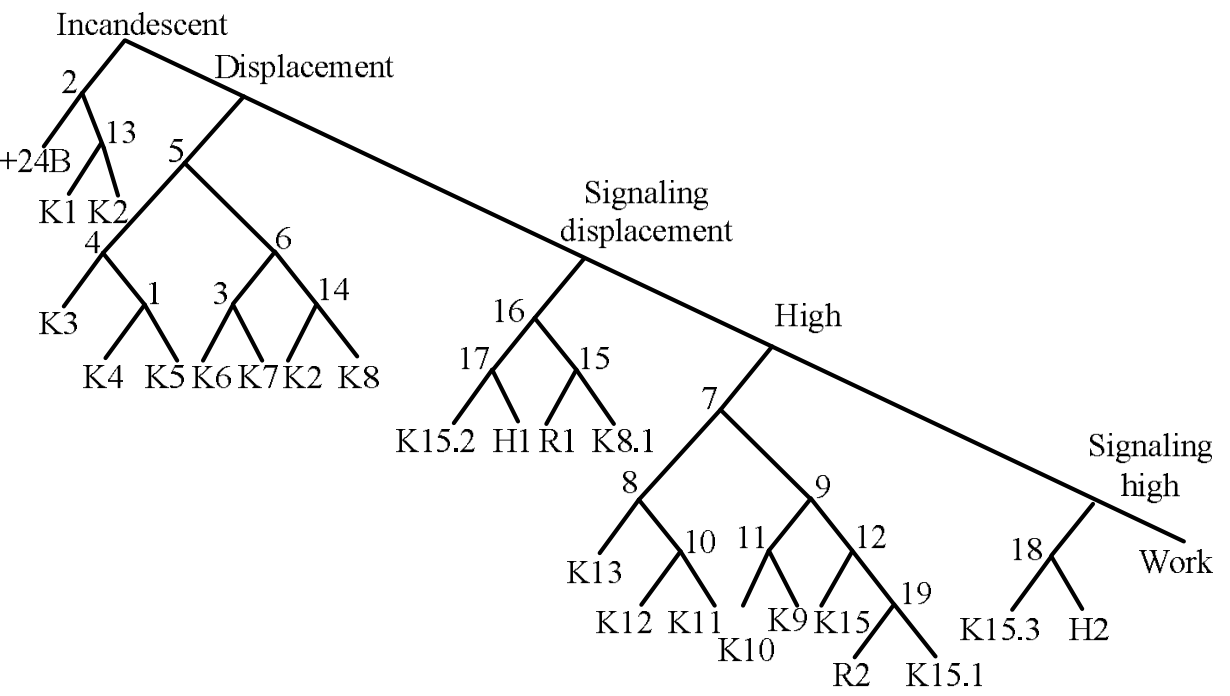

Fig. 2. Conditional algorithm for diagnostics of the subsystem of control of the operation of the radio transmitter 
In this case again $t=3 \mathrm{~min}$ and $t_{t r s}=5 \mathrm{~min}$. In case of failure of a known operation mode of one has $K=2$ and $T r \leq 30 \mathrm{~min}$.

The use of the electric measuring instrument C-4353 without taking into account the metrological reliability leads to the result

$$
\operatorname{Tr}=\frac{2 \cdot 3+5}{0,845^{6}}=15 \min <T p,
$$

and for the metrological reliability the device taking into account we find

$$
\operatorname{Tr}=\frac{2 \cdot 3+5}{0,877 \cdot 0,845^{2}}=17 \min <\operatorname{Tp}
$$

which is $13 \%$ more than in the previous case.

\section{Conclusions}

1. Functional dependences of the influence of the metrological reliability of the MI on the mean time of restoration of the MCM are obtained and examples of their practical use are given.

2. Account for the metrological reliability of the $\mathrm{MI}$ in estimation of the time of maintenance and CR of the MCM significantly increases the accuracy of the obtained results.

3. It is recommended to use the obtained results in the methods $[10,11]$, which will for more objective estimation of the time of execution of work and for the justification of the choice of the MI with the minimum necessary values of metrological characteristics to reduce the cost of maintenance and $\mathrm{CR}$ of the MCM.

\section{СПИСОК ЛІТЕРАТУРИ}

1. Ксёнз С. П. Диагностика и ремонтопригодность радиоэлектронных средств / С. П. Ксёнз. - М.: Радио и связь, 1989. $248 \mathrm{c}$.

2. Сакович Л. Н. Определение метрологических характеристик средств измерений для обслуживания и ремонта средств связи / Л. Н. Сакович, В. Н. Дзюба, В. П. Павлов // Зв'язок. - 2003. - № 5. - С.17-19.

3. Ryzhov Ye. Minimization measurement requirements for maintenance and repair special communication means / Ye. Ryzhov, L. Sacovych // Institute of Special Communication and Information Protection National Technical University of Ukraine "Igor Sikorsky Kyiv Polytechnic Institute" Scientific works "Information Technology and Security". - 2017. Vol. 5, Iss. 1(8). - P. 106-114.

4. Рижов С. В. Методика обгрунтування метрологічних характеристик засобів вимірювальної техніки військового призначення для метрологічного обслуговування військової техніки зв'язку / Є. В. Рижов, М. Ю. Яковлев // “Перспективи розвитку озброєння та військової техніки Сухопутних військ”: тези доповідей Міжнародної науково-технічної конференції. - Львів: АСВ, 2015. - С. 166-167.

5. Павлов В. П. Методики дефектации военной техники связи при неплановых ремонтах: дис. ... канд. техн. наук: 20.02.14 / Павлов В. П. - К., 2006. - 182 с.

6. Ким К. К. Метрология, стандартизация, сертификация и электроизмерительная техника: учебное пос. / К. К. Ким. СПб. : Питер, 2008. - 368 с.

7. Яковлев М. Ю. Розвиток теорії метрологічної надійності засобів вимірювальної техніки військового призначення : автореф. дис. ... докт. техн. наук: спец. 05.01.02 - стандартизація, сертифікація та метрологічне забезпечення / М. Ю. Яковлев - Львів, 2011. - 39 с.

8. Кононов В. Б. Визначення міжповірочних (калібрувальних) інтервалів засобів вимірювальної техніки військового призначення / В. Б. Кононов // Авиационно-космическая техника и технология. - 2011. - № 7. - С. 235-237.

9. Основи експлуатації засобів вимірювальної техніки військового призначення в умовах проведення АТО / В. Б. Кононов, О. В. Водолажко, О. В. Коваль та ін. - Х. : ХНУПС, 2017. - 288 с.

10. Удосконалення методу завдання вимог до мінімально припустимого значення ймовірності правильної оцінки результату виконання перевірки під час діагностування / М. Ю. Яковлев, Є. В. Рижов, Л. М. Сакович, П. Л. Аркушенко // Наука і техніка Повітряних Сил Збройних Сил України. - 2017. - № 4(29). - С. 136-142.

11. Рижов Є. В. Метод обгрунтування мінімально припустимого значення ймовірності оцінки результату перевірки параметрів / Є. В. Рижов, Л. М. Сакович // Вісник Національного технічного університету України "Київський політехнічний інститут". Серія Приладобудування. - 2017. - Вип. 54(2). - С. 96-106.

DOI: https://doi.org/10.20535/1970.54(2).2017.119562.

12. Цибина А. А. Опыт внедрения на ЭВМ методики установления межповерочных интервалов / А. А. Цибина, А. М. Шолов // Измерительная техника. - 2008. - № 1. - С. 16-17.

13. Сакович Л. М. Моделювання роботи апаратної технічного забезпечення / Л. М. Сакович, І. М. Гиренко // Сучасні інформаційні технології у сфері безпеки та оборони. - № 1 (28). - К.: НУОУ, 2017. - С. 47-52.

14. Короткохвильова радіостанція Р-1150. Посібник по експлуатації ААНЗ.464414.001 РЭ - Одеса : Телекард-Прилад, 2013. -205 c.

\section{REFERENCES}

1. Ksenz, S.P. (1989), Diagnostics and maintainability of radio-electronic means, Radio and communication, Moscow, 248 p.,

2. Sakovich, L.N. Dzyuba, V.N. and Pavlov V.P. (2003), "Definition of metrological characteristics of measuring instruments for maintenance and repair of communication equipment", Communication, No. 5, pp. 17-19.

3. Ryzhov, Ye. and Sacovych L. (2017), "Minimization measurement requirements for maintenance and repair special communication means", Information Technology and Security, Institute of Special Communication and Information Protection National Technical University of Ukraine (Igor Sikorsky Kyiv Polytechnic Institute), Kyiv, Vol. 5, Iss. 1(8), pp. 106-114. 
4. Ryzhov, Ye.V. and Yakovlev, M.Yu. (2015), "Methodology of substantiation of metrological characteristics of military equipment measuring equipment for metrological maintenance of military communication technique", Prospects for the Development of Arms and Military Equipment of the Land Forces : abstracts of the reports of the International Scientific and Technical Conference, LFA, Lviv, pp. 166-167.

5. Pavlov, V.P. (2006), Methods of defectation of military communication means during unplanned repairs, diss. PhD (technical sciences) : 20.02.14, Kyiv, $182 \mathrm{p}$.

6. Kim, K.K. (2008), Metrology, standardization, certification and electrical measuring equipment, Peter, St. Petersburg, 368 p.

7. Yakovlev M.Yu. (2011), Development of the theory of metrological reliability of means of measuring equipment for military use : author's abstract, diss. $\mathrm{PhD}$ (technical sciences) : special 05.01 .02 - standardization, certification and metrological support, Lviv, $39 \mathrm{p}$.

8. Kononov, V.B. (2011), "Determination of inter-verification (calibration) intervals of measuring equipment for military use", Aviation-space technology and technology, No. 7, pp. 235-237.

9. .Kononov, V.B., Vodolazhko, O.V. and Koval O.V. (2017), Fundamentals of operation of measuring instruments for military purposes under the conditions of ATO, KhNUPS, Kharkiv, $288 \mathrm{p}$.

10. Yakovlev, M.Yu., Ryzhov, Ye.V., Sakovich, L.M. and Arkushenko P.L. (2017), "Improvement of the method of task requirements to the minimum acceptable value of the probability of correct estimation of the result of the verification during the diagnosis", Science and technology of the Air Forces of the Armed Forces of Ukraine, No. 4 (29), pp. 136-142.

11. Ryzhov, Ye. and Sacovych, L. (2017), "Method substantiation of minimally possible value of probability assessment of estimation result of parameters", Bulletin of National Technical University of Ukraine "Kyiv Polytechnic Institute". Series Instrument Making, No. 54(2), pp. 96-106, doi: https://doi.org/10.20535/1970.54(2).2017.119562.

12. Tsybyna, A.A. and Sholov, A.M. (2008), "Experience in introducing on-computer methods for establishing intercheckpoints", Measuring technique, No. 1, pp. 16-17.

13. Sakovich, L.M. and Girenko I.M. (2017), "Modeling of hardware technical support", Modern information technologies in the field of security and defense, Kyiv, No. 1 (28), pp. 47-52.

14. Shortwave radio station R-1150 Operating manual AANZ.464414.001 RE, Telecard-Device, Odesa, 205 p.

Received (Надійшла) 26.01.2018

Accepted for publication (Прийнята до друку) 04.04.2018

\title{
Залежність показників ремонтопридатності військової техніки зв'язку від якості метрологічного забезпечення
}

\author{
В. Б. Кононов, С. В. Рижов, Л. М. Сакович
}

У статті запропонований підхід до кількісної оцінки впливу метрологічної надійності засобів вимірювальної техніки на час виконання перевірки параметрів військової техніки зв'язку при її технічному обслуговуванні і поточному ремонті. У відомих роботах для цього використовують приблизні значення імовірності безвідмовної роботи засобів вимірювальної техніки, що знижує точність отриманих результатів. В польових умовах необхідно враховувати метрологічну надійність засобів вимірювальної техніки, що залежить від температури, вологості, вібраційних навантажень та інших факторів. Час встановлення технічного стану військової техніки зв'язку регламентований керівними документами, тому для планування ефективної роботи фахівців під час ії технічного обслуговування та поточного ремонту в процесі розробки метрологічного та діагностичного забезпечення необхідне врахування всіх факторів, які впливають на значення показників ремонтопридатності. Запропоновано використовувати функціональні залежності середнього часу відновлення військової техніки зв'язку від показників якості метрологічного та діагностичного забезпечення. Приведено приклади використання результатів дослідження для кількісної оцінки показників ремонтопридатності реальних зразків військової техніки зв'язку та показано виграш в точності розрахунку середнього часу їх відновлення. Отримані результати дозволяють більш об' єктивно оцінити час виконання робіт та обгрунтовано обирати засоби вимірювальної техніки.

Ключов і слов а: військова техніка зв'язку; засоби вимірювальної техніки; метрологічне забезпечення.

\section{Зависимость показателей ремонтопригодности военной техники связи от качества метрологического обеспечения}

\section{В. Б. Кононов, Е. В. Рыжов, Л. Н. Сакович}

В статье предложен подход к количественной оценке влияния метрологической надежности средств измерительной техники на время выполнения проверки параметров военной техники связи при её техническом обслуживании и текущем ремонте. В известных работах для этого используют приближённые значения вероятности безотказной работы средств измерительной техники, что снижает точность полученных результатов. В полевых условиях необходимо учитывать метрологическую надежность средств измерительной техники, которая зависит от температуры, влажности, вибрационных нагрузок и других факторов. Время определения технического состояния военной техники связи регламентировано руководящими документами, поэтому для планирования эффективной работы специалистов во время ее технического обслуживания и текущего ремонта в процессе разработки метрологического и диагностического обеспечения необходим учет всех факторов, влияющих на значения показателей ремонтопригодности. Предложено использовать функциональные зависимости среднего времени восстановления военной техники связи от показателей качества метрологического и диагностического обеспечения. Приведены примеры использования результатов исследования для количественной оценки показателей ремонтопригодности реальных образцов военной техники связи и показан выигрыш в точности расчета среднего времени их восстановления. Полученные результаты позволяют более объективно оценить время выполнения работ и обоснованно выбирать средства измерительной техники.

Ключевые слов : военная техника связи; средства измерительной техники; метрологическое обеспечение. 